\title{
THE EFFECTIVENESS OF SKIMMING - SCANNING STRATEGY IN IMPROVING STUDENTS' READING COMPREHENSION AT THE SECOND GRADE OF SMK DARUSSALAM MAKASSAR
}

\author{
Andi Asmawati \\ State University of Makassar \\ Asma_wh@yahoo.com
}

\begin{abstract}
The objective of this research is to find out the effectiveness of Skimming-Scanning Strategy in improving students reading comprehension. It covered students' literal, inferential, critical comprehension in three types of text. They were narrative, descriptive, and news item texts. The research applied quasi experimental design. The subject of the research was the second grade students of SMK Darussalam Makassar. The data collected were the students' reading achievement through test (pretest and posttest). This research was divided into two groups, experimental and control group, the groups consisted of 28 and 27 students, respectively. The result of the data analysis showed that t-test was higher than t-table $(6.373>2.000)$ or Pvalue (Sig.) was smaller than alpha $(0.000<0.05)$. It meant that mean score of the experimental group was higher than the control group.
\end{abstract}

KEY WORDS: skimming-scanning, reading comprehension levels, three type texts.

\section{A. INTRODUCTION}

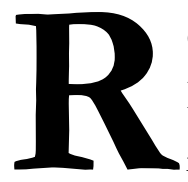

eading is one of the four necessary language skills for those learning English as a second or foreign language (ESL/EFL). Reading holds the important rule because reading is one activity which cannot be released

in our life to search information or knowledge from textbooks, articles, or magazines written in English. Thus, the students should have good reading skills to help them in academic studies.

Comprehending the text is one of the problems that the students face in reading. They cannot focus on what they read during the reading activity and still have difficulty to get the ideas of the text. Answering reading comprehension test will be time consuming if they use inappropriate strategies. Another problem is that not every detail of information in the passage is needed to answer the reading questions but students usually read the reading passage word by word. Reading a text word by word also makes them quickly forget what they have read. 
Andi Asmawati, The Effectiveness of Skimming - Scanning Strategy In Improving Students'...

Based on the informal interview with the English teacher in SMK Darussalam Makassar, 18 ${ }^{\text {th }}$ January 2014, the students have low skills in comprehending English texts and have low participation in the teaching and learning process because they are difficult to understand and catch the information in the reading text, when the students do the exercise in the text; they have difficulty to answer the questions because they do not know the content of the text. Besides the that reasons, another thing that makes the writer interested in conducting this research is the research findings of a qualitative research found by Tamsi et al. (2013) which showed that the teacher was not fully successful in implementing skimming and scanning strategies in teaching reading narrative text. It happened because there were still some steps proposed by Anne Arundel in Reading Study and Skill Lab (1999) which were not applied by the teacher.

Referring to the problems found and previous research findings related to reading comprehension, this research is going to establish how the effectiveness of skimming and scanning strategies in reading classroom by applying all the steps proposed by Anne Arundel (1999). Skimming-scanning is the strategy in teaching reading comprehension. Skimming-scanning strategy is required to help students comprehending a text, getting detailed information and other reading tasks.

\section{Review of related literature}

Research about the use of Peer Editing in teaching-learning process has been done by several researchers. However, they conducted a research with different points of view and different methods. Hamra and Syatriana (2010) in their article entitled "Developing a Model of Teaching Reading Comprehension for EFL Students" stated that reading is a skill that needs exercises. The exercises should consider the reading knowledge, prior knowledge, reading strategies, and reading participation. The learning and teaching process should be designed in such a way to increase the reading motivation and interest of the students. They also suggested an alternative model namely The Interactive Model of Teaching Reading Comprehension (IMTRC) to improve the reading comprehension of EFL students. Another alternative that they proposed was Model of Teaching Reading (Hamra and Syatriana, 2012). Another related research was conducted by Iravani and Atghia-ee (2013), from Payam-e-noor University, Iran. The research was about the effects of skimming and scanning via a multimedia $\mathrm{CD}$ on the reading comprehension. The quasiexperimental approach was used in this study. Findings indicated that the students in 
the experimental group performed better $(29.5 \%)$ than those in the control. It can be concluded that although traditional teaching methods used for reading skills can positively impact students, the use of innovative approaches (i.e. computer assisted language learning) can offer better results. Tamsi et al. (2013) also conducted a qualitative research entitled "The Implementation of Skimming and Scanning Strategies in Teaching Reading Narrative Text to the Tenth Grade Students of SMAN 21 Surabaya". The result of this study showed that the teacher was not fully successful in implementing skimming and scanning strategies in teaching reading narrative text. The reason because there were still some steps that were not applied by the teacher. While based on the questionnaire that has been answered by the students, it can be seen that the students' response toward skimming and scanning strategies was good. Abdelrahman and Bsharahin (2014) in their article, "The Effect of Speed Reading Strategies on Developing Reading Comprehension among the 2nd Secondary Students in English Language" found the results of this study showed that there was a significant difference on reading comprehension due to speed reading strategies through skimming and scanning which indicated that training was effective for the experimental group. The training procedures and the instructional activities improved the students' performance on the reading comprehension scale.

Skimming-scanning is the strategy in teaching reading comprehension. Harmer (2001: 202) stated that skimming is a technique in looking for a text to get a quick idea of the gist of a text. While, scanning strategy is the strategy for quickly finding specific information in a text while ignoring its broader meaning (Brown, 2001). Both of the strategies help the students to read in a more focused and efficient way. Therefore, skimming-scanning strategy is accelerated reading strategy to quickly looking for the idea and specific information of the text. Skimming-scanning is a speed reading strategy. This strategy has purpose to get the ideas and specific information of the text quickly. According to Brown (2004: 213) skimming is the process of rapid coverage of reading matter to determine its gist or main idea. In addition, Maxwell (1970) stated that scanning is the ability to locate specific facts and details quickly. Skimming-scanning is regarded as a desirable reading skill and it is taught in most developmental reading courses because it helps students to get information easily in efficient way.

According to Arundel in Reading and Study Skill Lab (1999), skimming is a strategy of rapidly moving the eyes over the text with the purpose of getting only the main ideas and the general overview of the content. Furthermore, there are steps in 
Andi Asmawati, The Effectiveness of Skimming - Scanning Strategy In Improving Students'...

applying skimming strategy, those are: (1) Read the title, (2) Read the introduction of lead paragraph, (3) Read the first paragraph completely, if there are subheadings, read each one, looking for relationship among them, (4) Read the first sentence of each remaining paragraph, (5) Dip into the text to looking for clue words, proper noun, unusual words, enumeration, qualifying adjective, typographical cues, (6) Read the final paragraph completely. She also presented several steps to maximize the use of scanning system on reading comprehension: (1) Keep in mind at all the time what is you are searching for, (2) Anticipate in what form the information is likely to appear numbers, proper nouns, etc (3) Analyze the organization of the content before starting to scan. If the material is familiar or fairly brief, we may able to scan the entire article in a single search. But if the material is long or difficult, it may be necessary to determine which part of the article to scan. (4) Let your eyes run rapidly over several lines of print at a time, (5) Read the entire sentence when you find the sentence that has the information you seek.

Based on the information above, it may be concluded that skimming and scanning strategies could be used by the students to comprehend narrative text'

\section{Aimed of the study}

The aimed of the research is going to investigate the effectiveness of skimming-scanning strategy in teaching reading in order to improve the students' reading comprehension.

\section{B. METHODOLOGY}

This research used quasi experimental with nonequivalent group design which involved two groups. They were experimental and control group. The two groups represented the experimental and control group from two skill competences, they were Automotive Technique of Easy Transportation (KR) and Automotive Technique of Motorcycle (SM) groups, respectively. KR group consisted of 28 students and SM group consisted of 27 students.

The instrument employed in the present study was reading test. The reading comprehension test was aimed at measuring students' reading comprehension in narrative, descriptive, and news item texts toward the use of skimming-scanning strategy. The reading test model was objective test in multiple choice tests. Before giving treatment, the researcher provided a reading test as a pre-test for both of experimental and control group. The purpose of the test was to recognize the two 
groups' level before starting the experimental program and to compare the results of the pre-test with the result of the post-test after the intervention.

\section{Data analysis and results}

\section{a. The improvement of students' reading comprehension}

An independent samples t-test was conducted to determine whether the experimental group scored significantly higher than the control group on the mean scores of the pre and post-reading comprehension tests.

Table 1. The Students' Pre and Post-Reading Comprehension Test Result

\begin{tabular}{llccccc}
\hline & Group & N & Mean & S.D. & Sig. (2-tailed) & Gain \\
\hline Pretest & Experiment & 28 & 54.6 & 9.04 & 0.929 & \\
& Control & 27 & 54.41 & 8.77 & & \\
\hline \multirow{2}{*}{ Posttest } & Experiment & 28 & 71.98 & 6.92 & 0.000 & 17.38 \\
& Control & 27 & 58.22 & 7.12 & & 3.81 \\
\hline
\end{tabular}

Based on the table 1, it showed that the total number students were 53 students which consisted of 28 students in experimental group and 27 students in control group. The comparison of the mean scores of the pre and post-reading comprehension tests shows a gain of 17.38 for the experimental group, and a gain of 3.81 for the control group.

The hypotheses were tested by using inferential analysis. In this case, the researcher used t-test (testing of significance) or Independent-Sample t-test to know the significant difference between the results of students' means score of two groups (experimental and control group). The result of t-test could be seen in table 4.4 as follows:

Table 2. The t-test analysis

\begin{tabular}{ccccc}
\hline Variable & t-test & Df & t-table & Sig. (2-tiled) \\
\hline Post-test & 6.373 & 53 & 2.000 & 0.000 \\
\hline
\end{tabular}

The table 2 indicated there was significant difference between t-table and ttest. The $\mathrm{t}$-test was higher than $\mathrm{t}$-table or $6.373>2.000$. It meant after treatment the students`reading comprehension increased. 
Andi Asmawati, The Effectiveness of Skimming - Scanning Strategy In Improving Students'...

\section{b. The students' improvement of three level of reading comprehension}

Table 3. The Pre and Post-test Mean Score and Standard Deviation of Students' Three Level Reading Comprehension

\begin{tabular}{lllccccc}
\hline \multirow{2}{*}{ Group } & \multicolumn{2}{c}{$\begin{array}{c}\text { Literal } \\
\text { Comprehension }\end{array}$} & \multicolumn{2}{c}{$\begin{array}{c}\text { Inferential } \\
\text { Comprehension }\end{array}$} & \multicolumn{2}{c}{$\begin{array}{c}\text { Critical } \\
\text { Comprehension }\end{array}$} \\
\cline { 3 - 8 } & & Mean & SD & Mean & SD & Mean & SD \\
\hline \multirow{2}{*}{ Pretest } & Experiment & 75.35 & 17.10 & 50.35 & 18.15 & 38.21 & 16.34 \\
& Control & 76.29 & 16.20 & 50.55 & 18.60 & 37.03 & 11.37 \\
\hline \multirow{2}{*}{ Posttest } & Experiment & 78.57 & 12.97 & 75.00 & 13.74 & 62.50 & 15.54 \\
& Control & 75.55 & 14.23 & 58.14 & 12.10 & 40.37 & 10.55 \\
\hline
\end{tabular}

Table 3 indicated that there was no significant difference between the students' mean score and standard deviation in three level reading comprehensions both of groups in pretest. After getting treatment, both of groups got improvement in inferential and critical levels of reading comprehension. Only literal level decreased in control group.

In this case, the researcher used paired t-test to know the significant difference between the students' level comprehension means score of pretest and posttest in both of groups (experimental and control groups). The result of paired ttest could be seen as follows:

Table 4. The Paired T-test Analysis of Experimental Group

\begin{tabular}{lllll}
\hline Variable & t-test & Df & t-table & Sig. (2-tiled) \\
\hline Literal & 1.071 & 27 & 2.052 & 0.294 \\
Inferential & 5.921 & 27 & 2.052 & 0.000 \\
Critical & 8.422 & 27 & 2.052 & 0.000 \\
\hline
\end{tabular}

The table 4. indicated there was significant difference between t-table and ttest in inferential and critical level after treatment by using Skimming-Scanning strategy. The statement was proved by the t-test value of inferential comprehension (5.921) and critical comprehension (8.422) which higher than t-table value (2.052), at the level of significance 0.05 and the degree of freedom $(\mathrm{N}-1)=(28-1)=27$, or sig. (2-tailed) is smaller than $\alpha(0.000<0.05, \mathrm{df}=27)$. However, there was not significant difference between $\mathrm{t}$-table and t-test in literal comprehension where t-test value was 
Volume I, Number 01, June 2015

smaller than t-table $(1.071<2.052)$ or sig. $(2$-tailed $)$ is higher than $\alpha(0.294>0.05$, $\mathrm{df}=27)$.

Table 5. The Paired T-test Analysis of Control Group

\begin{tabular}{lcccl}
\hline Variable & t-test & Df & t-table & Sig. (2-tiled) \\
\hline Literal & -0.217 & 26 & 2.056 & 0.830 \\
Inferential & 2.137 & 26 & 2.056 & 0.042 \\
Critical & 1.275 & 26 & 2.056 & 0.214 \\
\hline
\end{tabular}

The table 5 indicated there was significant difference between $\mathrm{t}$-table and $\mathrm{t}$ test in inferential level after treatment by using Direct Reading-Thinking Activity (DRTA) Strategy. The statement was proved by the t-test value of inferential comprehension (2.135) which higher than t-table value (2.056), at the level of significance 0.05 and the degree of freedom $(\mathrm{N}-1)=(27-1)=26$, or sig. $(2$-tailed $)$ is smaller than $\alpha(0.000<0.05, \mathrm{df}=26)$. However, there was not significant difference between t-table and t-test in literal and critical comprehension where t-test value was smaller than $\mathrm{t}$-table, $(-0.217<2.056)$ and $(1.275<2.056)$, or sig. $(2$-tailed) is higher than $\alpha$ $(0.830>0.05, \mathrm{df}=26)$ and $(0.214>0.05, \mathrm{df}=26)$.

c. The improvement of students' three types of reading comprehension text

Table 6. The Pre and Post-test Mean Score and Standard Deviation of Students' Three Types Text of Reading Comprehension

\begin{tabular}{lllccccc}
\hline \multirow{2}{*}{ Group } & \multicolumn{2}{c}{$\begin{array}{c}\text { Narrative } \\
\text { (N) }\end{array}$} & \multicolumn{2}{c}{$\begin{array}{c}\text { Descriptive } \\
\text { (D) }\end{array}$} & \multicolumn{2}{c}{$\begin{array}{c}\text { News Item } \\
(\mathbf{N I})\end{array}$} \\
\cline { 3 - 8 } & & Mean & SD & Mean & SD & Mean & SD \\
\hline \multirow{3}{*}{ Pretest } & Experiment & 56.78 & 15.88 & 52.50 & 17.76 & 54.75 & 16.39 \\
& Control & 55.18 & 12.51 & 53.70 & 17.79 & 54.44 & 16.25 \\
\hline \multirow{2}{*}{ Posttest } & Experiment & 72.50 & 12.94 & 73.21 & 12.18 & 69.28 & 14.12 \\
& Control & 62.96 & 14.88 & 54.81 & 13.69 & 56.29 & 13.05 \\
\hline
\end{tabular}

The table 6 showed the students' mean score and standard deviation in three types of reading comprehension that the researcher used in this research. The data indicated that there was not significant difference between the students' mean score and standard deviation in three type texts of the reading comprehensions both of 
Andi Asmawati, The Effectiveness of Skimming - Scanning Strategy In Improving Students'...

groups in pretest. After getting treatment, both of groups got improvement in narrative, descriptive, and news item text of reading comprehension.

The researcher used paired t-test to know the significant difference between the students' reading comprehension mean scores of three types text in pretest and posttest for both of groups (experimental and control groups). The result of paired ttest could be seen as follows:

Table 7. The Paired T-test Analysis of Experimental Group

\begin{tabular}{lllll}
\hline Variable & t-test & df & t-table & Sig. (2-tiled) \\
\hline Narrative & 5.943 & 27 & 2.052 & 0.000 \\
Descriptive & 4.923 & 27 & 2.052 & 0.000 \\
News Item Text & 5.079 & 27 & 2.052 & 0.000 \\
\hline
\end{tabular}

The table 7 indicated there was significant difference between t-table and ttest in narrative, descriptive, and news item text after treatment by using SkimmingScanning strategy. The statement was proved by the t-test value of narrative text (5.943), descriptive text (4.923), and news item text (5.079) which higher than t-table value (2.052), at the level of significance 0.05 and the degree of freedom $(\mathrm{N}-1)=$ $(28-1)=27$, or sig. $(2$-tailed $)$ is smaller than $\alpha(0.000<0.05, \mathrm{df}=27)$.

Table 8. The Paired T-test Analysis of Control Group

\begin{tabular}{lcccl}
\hline Variable & t-test & Df & t-table & Sig. (2-tiled) \\
\hline Narrative & 2.840 & 26 & 2.056 & 0.009 \\
Descriptive & 0.372 & 26 & 2.056 & 0.713 \\
News Item Text & 0.756 & 26 & 2.056 & 0.456 \\
\hline
\end{tabular}

The table 8 indicated there was significant difference between t-table and ttest in narrative text after treatment by using Direct Reading-Thinking Activity (DRTA) Strategy. The statement was proved by the t-test value of narrative text (2.480) which higher than $\mathrm{t}$-table value (2.056), at the level of significance 0.05 and the degree of freedom $(\mathrm{N}-1)=(27-1)=26$, or sig.(2-tailed) is smaller than $\alpha$ $(0.000<0.05, \mathrm{df}=26)$. However, there was not significant difference between t-table and $\mathrm{t}$-test in descriptive and news item text where $\mathrm{t}$-test value was smaller than $\mathrm{t}$ table, $(0.372<2.056)$ and $(0.756<2.056)$, or sig. $(2$-tailed $)$ is higher than $\alpha(0.830>0.05$, $\mathrm{df}=26)$ and $(0.214>0.05, \mathrm{df}=26)$. 
Volume I, Number 01, June 2015

\section{DISCUSSION}

Overall, the findings indicated that the students of experimental group improved their reading comprehension after treatment by using skimming-scanning strategy. During the treatment process, the researcher focused on improving reading skills through skimming-scanning strategy, students also carried out different activities about what they read such as answering questions or underlining the verbs.

The students at SMK Darussalam were not used to use skimming-scanning strategy, therefore when they had to do reading exercises they had difficulties because they did not understand the texts. The students thought that to understand a text they needed to know the meaning of every word. After conducting skimmingscanning strategy, the students realized that they did not need to know the meaning of all the words in a text in order to get the main idea. Diaz and Laguado (2013) in their action research found that skimming-scanning strategy helped students change their beliefs and perceptions about reading and transform their reading practice for the better.

The change of the students' habit from reading word by word to skim-scan the passage to answer the reading questions help students in their accelerated reading comprehension. In pretest, most of the students in control and experimental group did not answer some of the questions and complained the limited time (30 minutes) that the researcher gave. But, after treatment, some of the students in experimental group finished their posttest before the limited time. They just read and answered the questions as fast as they could. According to Brown (2004: 213) skimming is the process of rapid coverage of reading matter to determine its gist or main idea. In addition, Maxwell (1970) defined scanning as the ability to locate specific facts and details quickly it is regarded as a desirable reading skill and is taught in most developmental reading courses.

During the treatment, the researcher gave students limited time in some activities. She gave 2 minutes to the students to find out or underline the verb words in the passage. At the first meeting they read the passage word by word, not to skimscan the text so that they were slow to find the words. The researcher also gave limited time ( 2 or 3 minutes) when exercising the students in multiple choices. At the second meeting, the students getting better to use skimming-scanning to save their time in answering questions although most of them still slow in reading comprehension, but the next meeting they became faster and faster to find and answer the questions. Abdelrahman and Bsharahin (2014) stated that if the learner 
Andi Asmawati, The Effectiveness of Skimming - Scanning Strategy In Improving Students'...

wants to be fast in comprehending a text, he or she needs to practice skimmingscanning.

In terms of students' level of reading comprehension, most of the students got improvement in inferential and critical level comprehension in experimental group as showed in table 4.5. In these levels, the readers are required to get the ideas that are implied, to make an evaluative judgment about some aspect of the text, and to integrate the reading and thinking processes (Cooper et al., 1979: 29). It was also related to Maxwell (1970:7) stated that a preliminary skimming to locate main points not only serves to help the reader organize his ideas, but also increases his confidence that he can understand and retain the information.

Tamsi et al. (2013) conducted a qualitative research at SMAN 21 Surabaya. Based on the questionnaire that has been answered by the students, it can be seen that the students' response toward skimming and scanning strategies was good. The results also showed that the teacher was not fully successful in implementing skimming-scanning strategy in teaching reading narrative text. The reason because there were still some steps that were not applied by the teacher. But, after the researcher conducted skimming-scanning strategy in SMK Darussalam Makassar, the students showed different achievement in their posttest in narrative, descriptive, and news item text from pretest in experimental group which meant students' have good improvement in three types of text.

Based on the research result findings, the data showed that the differences of students reading comprehension after treatment are influenced by treatment given to them. It was proved by the result of statistical data analysis which indicated to the students' progress. Therefore, it can be concluded that there was a significant difference of students' reading comprehension before and after being taught by using Skimming-Scanning Strategy.

\section{REFERENCES}

Abdelrahman, M. S. H \& Bsharah, M. S. 2014. The Effect of Speed Reading Strategies on Developing Reading Comprehension among the 2nd Secondary Students in English Language. Article, (Online). (http://www.ccsenet.org/ journal/index.php/elt/article/viewFile/36962/20673, accessed on $6^{\text {th }}$ February 2014).

Alderson, J. Charles. 2000. Reading Assessing. New York: Cambridge University Press. 
Alvermann, D. E., Unrau, N. J., \& Ruddell, R. B. 2013. Models of Reading and Writing Process. International Reading Association. Article, (Online). (http://www.reading.org/Libraries/books/IRA-710-section3-intro.pdf, accessed on $6^{\text {th }}$ February 2014).

Anderson, N. J. 1991. Individual differences in strategy use in second language reading and testing. Modern Language Journal. Vol. 75: 460-472.

Anderson, R. C., E. H. Hiebert, J. A. Scott, \& I. A. G. Wilkinson. 1985. Becoming a nation of readers: The report of the Commission on Reading. Champaign: Center for the Study of Reading, Univ. of Illinois.

Antoni, Nurman. 2010. Exploring EFL Teachers' Strategies in Teaching Reading Comprehension. Jurnal Penelitian Pendidikan, (Online). Vol. 11, No. 2. (http:// jurnal.upi.edu/file/5-Nurman Antoni.pdf, accessed on $6^{\text {th }}$ February 2014).

Arikunto, Suharsimi. 2006. Prosedur Penelitian Suatu Pendekatan Praktik. Jakarta: Rineka Cipta.

Arundel, Anne. 1999. Reading and Study Skill Lab: Skimming and Scanning. Article, (Online). (http://www.aacc.edu/tutoring/file/skimming.pdf, accessed on $6^{\text {th }}$ February 2014).

Baratieri, Jacir Paulo. 2013. The Reading Process Models. Article, (Online). (http://baratieri.tripod.com/id24.html, accessed on $6^{\text {th }}$ February 2014).

Barnett, M. 1988. Teaching through context: How Real and Perceived Strategy Use Affect L2 Comprehension. The Modern Language Journal. Vol. 77, 150-162.

Bedoya, Lia D.S. M. 2013. Improving Reading Comprehension and Self-directed Learning through the Use of Explicit Reading Strategies and Personal Blogs on High School Students. Online Published Thesis. Chia:University de La Sabana.(http://intellectum.unisabana.edu.co:8080/ispui/bitstream/10818/94 24/1/Lia $\% 20$ de $\% 20 \% 20$ Socorro $\% 20$ Montalvo $\% 20$ Bedoya $\% 28$ Tesis $\% 29$.pd f, accessed on $6^{\text {th }}$ February 2014).

Benešová, Veronika. 2006. Testing Reading in English Language Teaching. Paper, (Online). (http:/ $/$ www.google.com/url? sa $=\mathrm{t} \& \mathrm{rct}=\mathrm{i} \& \mathrm{q}=\& \mathrm{esrc}=\mathrm{s} \&$ source $=$ web $\underline{\mathrm{ccd}}=14 \& \mathrm{cad}=$ rja\&uact $=8 \& \mathrm{kved}=0 \mathrm{CDoQFjADOAo \& url}=\mathrm{http} \% 3 \mathrm{~A} \% 2 \mathrm{~F} \% 2$ Fdspace.upce.cz \%2Fbitstream\%2F10195\%2F20371\%2F1\%2FD16164.pdf\& ei=XwAmU9L3C4SFrAe914GIAQ\&usg=AFQjCNEpmOh4oeDVTSChbbF EqnWIU QVVA\&bvm=bv.62922401,d.bmk, accessed on $6^{\text {th }}$ February 2014).

Bond, G. L., Tinker M. A., Wasson, B. B., \& Wasson, J.B. 1993. Reading Difficulties: Their Diagnosis and Correction. Needham Heights: Allyn and Bacon.

Brown, Douglas. 2004. Language Assessment Principles and Classroom Practices. New York: Pearson Education Ltd. 
Andi Asmawati, The Effectiveness of Skimming - Scanning Strategy In Improving Students'...

Brown, H. Douglas. 2001. Teaching by Principles: An Interactive Approach to Language Paedagogy. Second Edition. New York: Addison Weasley Longman,Inc. Pearson Education Company.

Cahyono \& Widiati. 2006. The Teaching of EFL Reading in The Indonesian Context: The State of Art. TEFLIN Journal, (Online). Vol. 17, No. 1. (Error! Hyperlink reference not valid., accessed on $6^{\text {th }}$ February 2014).

Carrell, P.L. and Eisenhold, J.C. 1989. Metacognitive Awareness and Second Language Reading. Modern Language Journal, (Online). Vol 73, Issue 2. (http://onlinelibrary.wiley.com/doi/10.1111/j.1540-4781.1989.tb02534.x/ abstract, accessed on $6^{\text {th }}$ February 2014).

Chavangklang, Pitchayapa. 2008. Assessing Reading Strategy Training Using a CallBased Approach for'Thai EFL Students' English Hyper Text Reading. Online Published Thesis. Thailand: Suranaree University of Technology. (Error! Hyperlink reference not valid., accessed on $6^{\text {th }}$ February 2014).

Cooper, J. D., Warncke, E. W., Ramstad, P. A., \& Shipman, D. A. 1979. The what and how of reading instruction. Columbus: Charles E. Merrill.

Damayanti, Yuanita. 2013. Implementing Skimming to Teach Reading Comprehension. Article, (Online). http://www.academia.edu/1142418/ Implementing_Skimming to Teach Reading_Comprehension, accessed on $6^{\text {th }}$ February 2014).

Diaz, Sindy \& Laguado J. C. 2013. Improving Reading Skills through Skimming and Scanning Techniques at a Public School: Action Research. Open Writing Doors, (Online). Vol. 10, No. 1. (http://revistas.unipamplona.edu.co/ojs viceinves/ index.php/OWD/article/view/240/230, accessed on $6^{\text {th }}$ February 2014).

Dorkchandra, Dentisak. 2010. Enhancing English Reading Comprehension through A Text Structure Reading Strategy CALL Program. Online Published Thesis. Thailand: Suranaree University of Technology. (http://sutir.sut.ac.th:8080/ sutir/bitstream/123456789/3708/2/fulltext.pdf, accessed on $6^{\text {th }}$ February 2014)

El-Deen, Zulfa Badr. 2009. The Effectiveness of Assisted Extensive Reading on Developing Reading Comprehension Strategies for Ninth Graders in Gaza Governorate. Online Published Thesis. Gaza: The Islamic University. (http:// library.iugaza.edu.ps/thesis/86895.pdf, Accessed on $6{ }^{\text {th }}$ February 2014)

El_Koumy, AS.AK. 2006. The Effects of the Directed Reading-Thinking Activity on EFL Students' Referential and Inferential Comprehension. (http:// files.eric.ed.gov/fulltext/ED502645.pdf, Accessed on $6^{\text {th }}$ February 2014).

Gay, L R, E. Mills, Geoffrey, and Airasian Peter. 2006. Educational Research: Competencies for Analysis and Applications. Eight Addition. United States: Pearson Merril Prenfice Hall. 
Volume I, Number 01, June 2015

Gilani, Mohammad RA , Ismail H.N, \& Gilakjani AP. 2012. Impacts of Learning Reading Strategy on Students' Reading Comprehension Proficiency. The International Journal of Language Learning and Applied Linguistics World (IJLLALW), (Online). Vo. 1 (1), 78-9. (Error! Hyperlink reference not valid., accessed on $6^{\text {th }}$ February 2014).

Glass, C. \& Zygouris-Coe, V. 2006. Directed Reading-Thinking Activity. Article, (Online). (https://www.ocps.net/cs/services/cs/currareas/read/IR/bestpractices/ AF/Directed $\% 20$ Reading $\% 20$ Activity.pdf, accessed on $6^{\text {th }}$ February 2014).

Grabe, W. 1991. Current developments in second language reading research. TESOL Quarterly, Vol. 25, 375-406.

Green, LB. \& Roth, KL. 2013. Increasing Inferential Reading Comprehension Skills: A Single Case Treatment Study. Canadian Journal of Speech-Language Pathology and Audiology, (Online). Vol. 37, No. 3. (http://209.217.105.25/ english/resources/database/files/2013 CJSLPA Vol 37/No 03 182245/Green Roth Fall 2013.pdf, accessed on $6^{\text {th }}$ February 2014).

Hamra, Arifuddin \& Syatriana. 2012. A Model of Reading Teaching for University EFL Students: Need Analysis and Model Design. Canadian Center of Science and Education, (Online) Vol. 5, No. 10. (http://www.ccsenet.org/journal/ index. $\mathrm{php} /$ elt/article/viewFile/19752/13030, Accessed on $6^{\text {th }}$ February 2014).

Hamra, Arifuddin \& Syatriana. 2010. Developing a Model of Teaching Reading Comprehension for EFL Students. TEFLIN journal,(Online), Vol. 28, Number 1. (http://journal.teflin.org/index.php/teflin/article/view/209/151, accessed on $6^{\text {th }}$ February 2014).

Harmer, J. 2001. The Practice of English Language Teaching. Third Edition. London: Longman.

Hong, N.C. 2013. Teaching of Skimming at Tertiary Level: Theoretical and Pedagogical Issues. International Journal of Bilingual \& Multilingual Teachers of English, (Online). No. 1, 1-7. (Error! Hyperlink reference not valid., accessed on $6^{\text {th }}$ February 2014)

Iravani, H. \& Atghia-ee, F. The Effects of Skimming and Scanning Via a Multimedia $\mathrm{CD}$ on the Reading Comprehension of Iranian Female English Translation Students. In Robertson, Paul (Ed.). The Iranian EFL Journal, (Online). June Vol. 9 Issue 3 2013. Iran: The Iranian EFL. (Error! Hyperlink reference not valid., accessed on $6^{\text {th }}$ February 2014).

Jabu, Baso. 2008. English Language Testing. Makassar: Badan Penerbit UNM.

Long, Michael \& Richards, J. 1987. Methodology in TESOL. Boston: Heinle \& Heinle Publishers.

MacLeod, Maija. 2013.Types of Reading. Article (Online). (http:// fis.ucalgary.ca/ Brian/ $\underline{611 / \text { readingtype.html\#whatitisintensive, }}$ accessed on $6^{\text {th }}$ February 2014) 
Andi Asmawati, The Effectiveness of Skimming - Scanning Strategy In Improving Students'...

Maxwell , Martha J. 1972. Skimming and Scanning Improvement: The Needs, Assumption and Knowledge Base. Journal of Reading Behavior, (Online). Vol. 5, No. 1, Winter. (http://jlr.sagepub.com/content/5/1/47.full.pdf, accessed on $6^{\text {th }}$ February 2014).

Mikulecky, S. Beatrice \& L. Jeffries. 2004. More Reading Power. New York: Pearson Education Ltd.

Munir, Ardi. 2012. Generic Structure and Example News Item Text. Article (Online). (http://smp3lembang.blogspot.com/2012/08/generic-structure-andexample-news-item.html, accessed on $6^{\text {th }}$ February 2014)

Munir, Nurasia. 2009. Using Shared Reading Strategy to Improve Reading Comprehension. Unpublished thesis. Makassar: Graduate Program of the State University of Makassar.

Nga, Nguyen T. T. 2009. Teachers' Beliefs about Teaching Reading Strategies and Their Classroom Practices: A Case Study of Viet Ba High School. Online Published Thesis.Vietnam: Vietnam National University. (http://www.asian-efljournal.com/Thesis-N-Nga.pdf, accessed on $6^{\text {th }}$ February 2014)

Nunan, David. (Ed.). 2003. Practical English Language Teaching. New York: McGraw Hill.

Nuttal, Christine. 2005. Teaching Reading Skills in a Foreign Language. Oxford: Macmillan.

O’Malley, J. \& Chamot, A. 1990. Learning strategies in second language acquisition. UK: Cambridge University Press.

Pang, E. S., Muaka A, Bernhardt, E. B., \& Kamil, M. L. Teaching Reading. International Academy and BUREAU of Education. Educational Practise Series 12 (Online). (https://smec.curtin.edu.au/local/docs/prac12e.pdf, accessed on $6^{\text {th }}$ February 2014).

Rahim, Fathur. 2009. Teaching Reading. Jakarta: MGMP Bermutu, (Online). (http://mmursyidpw.files.wordpress.com/2009/05/teachingreading.pdf, accessed on $6^{\text {th }}$ February 2014).

Royer, J. M. \& Cunningham D. J. 1978. The Theory and Measurement of Reading Comprehension. Massachusetts: The National Institute of Education.

Ruga, 2012. Definition Of Recount, Report, Narrative, Descriptive and Procedure Text. Article, (Online). (http://rugayamanan.wordpress.com/2012/ 12/08/definition-of-recount-report-narrative-descriptive-and-proceduretext/, accessed on $6^{\text {th }}$ February 2014).

Snow, Catherine E. 2002. Reading for Understanding : Toward a Research and Development Program in Reading Comprehension. Santa Monica: RAND Reading Study Group.

Tamsi, Resya K., Zuhri, F., \& Kurniasih, E. 2013. The Implementation of Skimming and Scanning Strategies in Teaching Reading Narrative Text to the Tenth 
Grade Students of SMAN 21 SURABAYA. Ejournal Unesa, (Online). Vol. 1, No.1. (http://ejournal.unesa.ac.id/index.php/retain/article/view/2618/bacaartikel, Accessed on $6^{\text {th }}$ February 2014).

Ueta, Tae. 2005. Teaching Reading. A Paper, (Online). (http://www.kochinet.ed.jp/ koukou/kenkyu/kaigaihaken/uetafinal.pdf, accessed on $6^{\text {th }}$ February 2014).

Williams, Eddle. 1984. Reading in the Language Classroom. London: Macmillan.

Yale, J B. 2008. The relationship between reading and writing. Article, (Online). (http://www.k12reader.com/the-relationship-between-reading-and-writing/, Accessed on $6^{\text {th }}$ February 2014)

Zadeh, Farnoush. 2012. Our Model of Reading Process. Article, (Online). (http://enableviatechnology.blogspot.com/2012/05/our-model-of-readingprocess-after-our.html, accessed on $6^{\text {th }}$ February 2014). 